\title{
Students' Participation in Quality Assurance Management and Tertiary Institutions Effectiveness in Nigeria
}

\author{
Ovat E. Okpa ${ }^{1}$, Francisca N. Odigwe ${ }^{1}$, Kelechi V. Emeribe ${ }^{1} \&$ Ebuara V. Obule ${ }^{1}$ \\ ${ }^{1}$ Department of Educational Management, University of Calabar, Calabar, Nigeria \\ Correspondence: Ovat E. Okpa, Department of Educational Management, University of Calabar, Calabar, Nigeria. \\ E-mail: okpaovat@gmail.com
}

Received: March 6, 2020

Accepted: August 13, $2020 \quad$ Online Published: November 23, 2020

doi:10.5539/ies.v13n12p41

URL: https://doi.org/10.5539/ies.v13n12p41

\begin{abstract}
The study investigated the level of students' participation in quality assurance management and tertiary institutions effectiveness in Nigeria. Four null hypotheses were formulated to guide the study. The design adopted was correlational research design. The population was made up of 423 2018/2019 session students' union officials. A sample of 160 was randomly selected from three (University of Calabar, Cross River University of Technology and Federal College of Education, Obudu) public tertiary institutions in the area. The instrument used for data collection was questionnaire (Students' Participation in Quality Assurance Management Questionnaire (SPQAMQ) validated by experts in test and measurement. It contained 28 items constructed in a 4-point Likert scale. Pearson Product Moment Correlation Statistics was used for data analysis. The result of the analysis revealed a significant positive relationship between students' participation in decision-making, discipline management, quality assurance committees and school plant maintenance and tertiary institution management when tested at 0.05 level of significance. Based on the findings it was recommended that students should be adequately motivated through quality participation in school governance to enhance their academic achievement and development of basic leadership skills.
\end{abstract}

Keywords: students, participation, quality assurance, management

\section{Introduction}

Students are full partners in the governance of tertiary institutions and they have an important role not only in quality assurance, but also in all decisions regarding tertiary education. Students are integral part of the quality control measures and are often at the centre of all quality assurance discourse and any educational process. They constitute the single most important input in the school system. Without students the school cannot exist. All the activities that go on in the school are aimed at developing their total personality to the fullest. It is on them that staff particularly teachers' work to achieve the overall educational objectives. This therefore demands that the tertiary institution mangers must implement good instructional programmes and provide opportunities for students to develop responsible attitudes and acquire good moral training that will prepare them for their future lives (Ozigi, 1982). According to Abenga (1995), the responsibility of the school administrator is to see that all school activities are directed towards developing to the fullest the potentiality of the student. If the student is to benefit from the education given by the school, his intellectual, physical, social and psychological needs as well as the educational needs of his society have to be well catered for in the student personnel services provided by the school.

Students are expected to participate or be involved in the collective administrative decision-making process of the school in order to make their contribution in matters that affects them directly like conduct of examination, evaluation of students performance, admission process, classroom management, appointment of teachers and other areas of school life (Jeruto \& Kiprop, 2011; Aggrawal, 2004). Students are critical stakeholders and their participation is a crucial process in which their viewpoints are harnessed to reach the best possible decision (Naidoo, 2004). Involving students in decision making process will give them a chance to express themselves in analyzing problems and suggesting possible improvement. Hannam (2003) argued that the benefits of student participation in the school include improved discipline, better student teacher relations, less exclusion, collective memory and more positive attitude towards school and school learning. Students have a tendency of supporting policy decisions they help to create as well as assuming more responsibility for school issues.

Discipline has always been a major concern for teachers and educators because it is a precursor of success in the 
school. As a function of school administration, it involves providing guidance and instruction in ways that will teach and enhance a healthy lifestyle and social order where the rights and responsibilities of students in the school are balanced. According to Mbiti's (1974) the main goal of discipline both in the school and in the home should be to produce young people who will be responsible when they become adults. Student leaders play a significant role in managing student discipline and are instrumental in inspiring and mentoring other students to respect the school rules and regulations (Kennedy, 2018). They are in closer touch with other students through peer interaction than the teachers are with them. They promote better discipline in schools. Integrating them into school discipline management will enhance sharing of trust, taking responsibility and accountability, and creating a sense of ownership of the school and its activities among students population.

School committees are an important aspect of participative management. They are established to assist in arriving at useful and meaningful decisions that will facilitate the attainment of school goals. They are a means of achieving coordination of activities and sharing information among various departments, units and divisions of the school; and consist of elected or appointed bodies responsible for decision making in public schools. Berghe (1978) maintained that students should be part of the school quality assurance management committee as this directly affects their personal well-being or welfare. He insisted that if students are allowed to participate in out-of-the-classroom activities it will help them to understand the importance of critical thinking skills, time management, and academic and intellectual competence. Also, they will learn how to negotiate, collaborate, communicate, manage conflict, and lead others.

School plant maintenance is important in facilitating and stimulating educational programmes. The right kind of atmosphere required for effective teaching and learning is the one consisting of better buildings and teaching facilities. This is because the quality of education students receive bears direct relevance to the availability or lack of facilities and overall atmosphere where learning takes place (Edem, 1982). If the building and facilities are kept at the same level of care and seriousness, high quality will extend to academic programmes. According to UNESCO (2008) students' participation in facility design and maintenance is critical to improving their morale and retention, and has been shown to have a significant impact on their performance. Mwikali (2015) findings affirmed that students' involvement in different school activities like maintenance of hygiene and sanitation lead to high performance and easy management. The students should therefore be involved in the maintenance of facilities. Dyment (2004) maintained that involving students in grounds improvement will draw on their energies and empower them with innovative grounds development skills, build self-confidence and help them take ownership of their work.

Quality assurance in education aims at ensuring the attainment of education targets and improvement in the process of education delivery. It is defined as a continuous process by which an institution can guarantee that standards and quality of its educational provisions are being maintained or enhanced (Standa, 2008). One of the most effective ways of involving the students directly in the governance of their school is by making use of the Student Union government system (Dahatonde, 2008). Through this certain duties connected with the day-to-day running of the school are delegated to the students. The students' union officials help the school managers and staff in solving problems or cases concerning discipline, sanitation, checking attendance at school activities, and students' general welfare. They help the school administration with discipline by ensuring that the students obey school rules and regulations.

Students play an important role in the overall functioning of the school. They have a major influence in decisions that affects the school culture (Jeruto \& Kiprop, 2011). They are responsible for providing quality leadership opportunities that transcend the campus experience and are applicable in one's future career path. Bajpai and Arasu (2008) stated that students should be involved in all processes relating to quality assurance and enhancement. Students' representative should be included on appropriate institutional bodies including governing bodies, policy committees and departmental committees as this will foster a greater sense of student ownership in matters of mutual concern and institutional development.

One of the methods of assisting students to develop political awareness and sensitivity is to give them the chance to participate in school governance. Meaningful forms of participation have meaning for the participant and contrast with disengaging forms of student participation often employed in schools. Forms of participation which have such meaning have been labeled 'active' participation (Holdsworth, 1997), 'authentic' participation (Cumming, 1994) and 'deep' participation (Wilson, 2000). These forms of participation are about students being active, taken seriously, listened to, and doing work of consequence. The notion of student voice is fundamental to deep participation. If students are to be accepted as participants and stakeholders in education, it is clear that their 'voice' becomes a critical factor in school management. 
Students can exercise participation in a variety of contexts within schools, most notably through their learning experiences, through involvement in formal school governance processes, and through student governance and other student-operated organizations within the school (Holdsworth, 1988). Students or learners are "equal partners" in the academic community and relevant stakeholders in higher education, who should be consulted in the course of quality assurance processes. But very few tertiary institutions in Nigeria have made effort to bring in the students into the internal quality assurance process. This is contrary to what obtains in some developing countries as well as the developed ones. Student participation in the quality assurance process has great gains such as providing valuable feedback on instructional effectiveness and courses taken, promotion of the students, imbibing of the institution's quality culture, inculcating sense of worth and responsibility into students. Their involvement contributes to improvement of not only their learning experiences but also in the overall development of the educational process (Archibong, 2013). The neglect of students' input particularly with respect to teaching and learning leaves a gap in tertiary institution's effort to improve quality. There is therefore an urgent need to establish suitable means of students' involvement in the internal quality assurance process in Nigerian public tertiary institutions.

\subsection{Statement of the Problem}

It has been observed that governance in tertiary institutions is still characterized by traditional modes of administration where decision making is vested on the provost, rector or vice chancellors and management board. The head of administration define who participates, how they participate, and what decisions are open to participation. Students are often left out of the many change processes schools undertake. They are often regarded as recipients or consumers of the decisions, programmes and activities of the school. Important decisions are made for and about them, yet they are not given meaningful consideration or opportunity for participation. Even in schools where students are asked to participate in the process, they are sometimes only given passive volunteer assignments and tasks to complete (Fletcher, 2003).

Despite societal changes, some tertiary institution managers still cling to the outmoded traditional and autocratic administrative styles that give little room for student involvement in governance. Indeed in some schools there is virtually no space for students to organize or speak about their concerns. As a result, students have resorted to violence as a means of getting their views across to their administrators. Confrontations between student activists and school administrators have caused new recognition of students' rights of participation in school management. If students are stakeholders just as their parents or guardians, what is the level of their involvement in quality assurance management in tertiary institutions in Cross River State? This study intends to find out the relationship between students participation in quality assurance management and tertiary institutions effectiveness in Cross River State.

\subsection{Research Questions}

To guide the study the following research questions were formulated:

1) How does students participation in decision making relate to tertiary institutions effectiveness?

2) How does students' participation in discipline management relate to tertiary institution effectiveness?

3) What is the extent to which students' membership in school quality assurance committees relate to tertiary institutions effectiveness?

4) Does students' participation in maintenance of school facilities relate to tertiary institutions effectiveness?

\subsection{Research Hypotheses}

1) Students' participation in decision making does not significantly relate to tertiary institutions effectiveness.

2) There is no significant relationship between students' participation in discipline management and tertiary institutions effectiveness.

3) Students' membership of school quality assurance committee does not significantly relate to tertiary institutions effectiveness.

4) Students' participation in maintenance of school facilities does not significantly relate to tertiary institution effectiveness.

\section{Methodology}

The methodology employed for study is described in this section. 


\subsection{Research Design}

The research design adopted for the study was correlational design. The design was considered appropriate because it attempts to find the nature of relationship between a set of variables in order to determine or estimate the extent to which the variables are related or change in an identifiable pattern. The direction of the relation between variables is described as being positive or negative.

\subsection{Participants}

The population was made up of 423 Students' Union officials for 2018/2019 session. The officials of the Students' Union were considered appropriate to participate in the study having participated in leadership role at the student union level.

\subsection{Sampling Procedure}

Stratified and simple random simple sampling techniques were used to select sample. The population was divided into strata based on groups within the university, while simple random sampling was used to select sample from each stratum. The sampling techniques were able to cater for the subgroups of interest within the population.

\subsubsection{Sample}

A sample of 160 students union officials were randomly selected from three public tertiary institutions (University of Calabar (Unical), Cross River University of Technology (CRUTECH) and Federal College of Education (FCE), Obudu) in the area. A breakdown of the sample size indicate as follows (Unical $=80, \mathrm{CRUTECH}=50, \mathrm{FCE}=30$ ).

\subsubsection{Measures}

The instrument used for data collection was questionnaire titled: Students' Participation in Quality Assurance Management Questionnaire (SPQAMQ). Draft copies of the instrument were validated by experts in test and measurement from the Faculty of Education, University of Calabar. This was to establish that fact that the content is truly asking the required questions that will provide answers to the problem under study. The SPQAMQ was divided into two sections. Section A - dealt with the respondents demographic data such as sex, age, marital status, school, and designation. Section B had - 28 questionnaire items in a four point Likert Scale model to measure students' participation in school management. The questionnaire was constructed by taking into consideration all the variables. Each variable was measured using four (4) items and each had four response options ranging from Strongly Agree (SA), Agree (A), Disagree (D) and Strongly Disagree. The reliability of the instrument was determined through a trial testing using 50 students drawn from the population with similar characteristics with the one under study. The reliability estimates ranged from 0.79 to 0.86 .

\section{Results}

\subsection{Statistics and Data Analysis}

Data was analyzed using mean and standard deviation and Pearson product moment correlation analysis.

Table 1. Pearson product moment correlation analysis of students participation in quality assurance and tertiary institution effectiveness $(n=160)$

\begin{tabular}{cccccc}
\hline Variables & $\mathrm{N}$ & $\overline{\mathrm{x}}$ & $\mathrm{SD}$ & $\mathrm{r}$-value \\
\cline { 2 - 6 } & Decision making & 160 & 22.0169 & 1.34543 & $0.38^{*}$ \\
Discipline management & & 18.4123 & 3.11997 & $0.42^{*}$ \\
Quality assurance committees & & 17.0754 & 1.34113 & $0.52^{*}$ \\
School plant maintenance & & 22.2031 & 1.90093 & $0.80^{*}$ \\
Institutional effectiveness & & 17.7631 & 2.65240 & \\
\hline
\end{tabular}

$\mathrm{p}>0.05, \mathrm{df}=158$, critical r-value 0.195 .

The result in Table 1 shows that the calculated r-value for participation in decision making of 0.38 is higher than the critical r-value of 0.195 when tested at .05 level of significance with 158 degrees of freedom. This implies that the result is significant. With this result, the null hypothesis that, there is no significant relationship between students participation in decision-making and tertiary institution effectiveness was rejected. The result also revealed that there is a significant positive relationship between students' participation in decision making and tertiary institution effectiveness. The positive (r) value implies that the higher the level of involvement of students in decision making, the more effective the management of institution will be and vice-versa. The positive 
relationship shows that tertiary institution management effectiveness increases with the participation of students in decision making. Thus the null hypothesis is rejected while the alternate hypothesis is accepted.

The result as presented in Table 1 also indicated that the calculated r-value for discipline management of 0.42 is higher than the critical r-value of 0.195 when tested at .05 level of significance with 158 degrees of freedom. This implies that the result is significant. With this result, the null hypothesis was rejected. The result of the analysis revealed that there is a significant positive relationship between students' participation in discipline management and tertiary institution effectiveness. The positive (r) value implies that the higher the participation of students, the more effective the management of tertiary institution and vice-versa. The positive relationship shows that participation of students in discipline management result in effective management of the institution. Thus the null hypothesis was rejected while the alternate hypothesis was retained.

The result of the analysis as presented in Table 1 further indicated that the calculated r-value for students' participation in school quality assurance committees of 0.52 is higher than the critical r-value of 0.195 when tested at .05 level of significance with 158 degrees of freedom. This implies that the result is significant. With this result, the null hypothesis that, there is no significant relationship between students' participation in school quality assurance committees and tertiary institution effectiveness was rejected. The result of the analysis revealed that there is a significant positive relationship between participation in school quality assurance committee and tertiary institution effectiveness. The positive (r) value implies that the higher the level of student participation in quality assurance school committees, the more effective the institutions and vice-versa. The positive relationship shows that tertiary institution effectiveness increases with the participation of students in school quality assurance committees. Thus the null hypothesis was rejected while the alternate hypothesis was retained.

The analysis in Table 1 revealed that the calculated r-value for school plant management of 0.80 is higher than the critical r-value of 0.195 when tested at .05 level of significance with 158 degrees of freedom. This implies that the result is significant. With this result, the null hypothesis was rejected. The result revealed a significant positive relationship between students' participation in school plant maintenance and tertiary institution effectiveness. The positive (r) value implies that the higher the quality of students' participation provided, the effective the school management and vice-versa. The positive relationship also shows that tertiary institution effectiveness increases with the participation of students in governance. Thus the null hypothesis was rejected while the alternate hypothesis was retained.

\section{Discussion}

The result of hypothesis one indicated that students' participation in decision-making has a strong positive relationship with secondary school management. The findings agrees with the result of Jeruto and Kiprop (2011) study on students' participation on decision making in schools in Kenya, that student' participation in school management helps to improve administration of the schools. It is also supported by Naidoo (2004) who identified students as stakeholders hence the need for their involvement in decision making. Participation is also about the situation of all stakeholders working together and making decisions in pursuit of common interest. Student participation therefore implies their inclusion at whatever level of schooling in decision making processes in their institutions. Students need to be aware of opportunities for involvement in decision making and administrators should make genuine efforts to include them and solicit their input in building healthier schools.

The result of hypothesis two indicated that students' participation in discipline management has a strong positive relationship with tertiary institution management. The finding affirms Mbiti's (1974) opinion that, the main goal of discipline both in the school and in the home should be to produce young people who will be responsible when they become adults. Such people should be able to make their own decisions and accept the consequences of these decisions like men. The process of managing student discipline in schools should start with the identification of the type of students enrolled in schools. It is only when the personal psychological make-up of the students is known that one can devise the appropriate methods of managing them to the desirable standard.

The result of hypothesis three indicated that participation in school committees has a strong positive relationship with tertiary institution management. The findings are in agreement with Berghe (1978) view that by working together with other individuals, students learn to negotiate, communicate, manage conflict, and lead others. Taking part in these out-of-the-classroom activities helps students to understand the importance of critical thinking skills, time management, and improve their academic and intellectual competence.

The result hypothesis four indicated that student participation in school plant management has a strong positive relationship with effective tertiary institution management. The findings are in agreement with Dyment (2004), findings that students who were involved in the greening project took tremendous ownership over their work. In addition to gaining ownership for and empowerment from the project, she opined that when students are involved 
in the greening project they learn about the power of collective action. The finding was also in line with the result of similar study by UNESCO (2008) which concluded that allowing students to participate in facility design and maintenance alone is not only critical to students' morale and retention, it has been shown to have a significant impact upon students' performance.

\section{Conclusion}

Quality educational outcomes are best achieved by harnessing students' motivation to participate in critical decision making process. As part of the human resources available to managers of institutions, students should be involved in processes culminating in attainment of schools goals. Their involvement and participation in school administration is an essential aspect of overall quality assurance and institutional quality. The outcome of this study generally revealed the need for greater incorporation of students in effective management of quality assurance in tertiary institution governance. As major stakeholders of their institutions, they must share the responsibility for their education and institutional development. Students should directly participate in the quality assurance administration as this will inculcate a sense of responsibility and ownership. It is inferred that tertiary institution management effectiveness increases where students are adequately involved in governance. The researchers are therefore of the opinion that the managers of these institutions should do everything within their power to get the students involved in school governance to enhance institutional effectiveness.

\section{Recommendations}

Based on the findings of the study the following recommendations were made:

1) Tertiary institution managers should explore and examine the various alternatives of students' participation in institutional quality assurance governance.

2) The managers of tertiary institutions should allow students voice their concerns about quality assurance by including them in school policy making processes.

3) Students should be allowed to sit in committees that deliberate on every aspects of school life in order for them to learn values of total inclusion, participation and empowerment; all of which are core elements of democratic culture.

\section{Acknowledgements}

The authors are deeply indebted to the various authorities whose works were cited and which provided a guide to this study. They are equally grateful to all the members of the students' union government of the three tertiary institutions who willingly participated in this study and the experts who did the face and content validities.

\section{References}

Abenga, F. M. (1995). Principles and practice of school administration in Nigeria. Markurdi: Onaivi printing.

Archibong, I. A. (2013). Strengthening internal quality assurance for improved education delivery in Nigerian public universities. Research on Humanities and Social Sciences, 3(1), 172-178.

Bajpai, A. N. D., \& Arasu, J. G. V. (2008). Student participation for quality enhancement in higher education. In D. George et al. (Eds.), Quality education, prospects and challenges. New Delhi: APH Publishing Corporation.

Berghe, P. L. (1978). Power and privilege in an African University. London: Routledge and Kegan Paul.

Cumming, J. (1994). Educating young adolescents: Targets and strategies for the 1990s. Curriculum Perspectives, 14(3), 41-44.

Dahatonde, S. A. (2008). Student participation and quality enhancement in higher education. In D. George, J. G. Valan Arasu, P. Agrawal, \& M. K. Gupta (Eds.), Quality Education: prospect and challenges. New Delphi: APH Publishing.

Dyment, J. E. (2004). “At That Age, You Just Accept What You Have... You Never Question Things”: Student Participation in School Ground Greening. Children Youth and Environments, 14(1), 130-152.

Edem, D. A. (1982). Introduction to Educational Administration in Nigeria. Ibadan: Spectrum Books Ltd.

Fletcher, A. (2003). Meaningful student involvement: Guide to inclusive school change. Olympia, WA: The Free child Project.

Hannam, D. (2001). A pilot study to evaluate the impact of the student participation aspects of the citizenship order on standards of education in secondary schools. London: CSV. 
Holdsworth, R. (1988). Student participation projects I Australia: An anecdotal history. In R. Slee (Ed.), Discipline and schools: A curriculum perspective. Melbourne: Macmillian.

Holdsworth, R. (1997). Student participation, connectedness and citizenship. Connect. Supporting Student Participation, 104, 17-21.

Jeruto, T. B., \& Kiprop, C. J. (2011). Extent of student participation in decision making in secondary schools in Kenya. International Journal of Humanities and Social Sciences, 1(21), 11-18.

Kennedy, O (2018). Managing student discipline through student leadership in Kenyan secondary school. European Journal of Research and Reflection in Education Sciences, 6(2), 1-9.

Magadla, M. (2007). The role of the learner in the school governing body: Perceptions and experiences of principals, educators, parents and learners (Unpublished M.Ed thesis). University of Kwazulu- Natal.

Mbiti, D. M. (1974). Foundations of School Administration. Oxford University Press.

Mwikali, N. L. (2015). Influence of student councils' involvement in management in public primary schools in Kangundo Sub County, Kenya. University of Nairobi, Kenya

Naidoo, J. (2004). Education decentralization and school governance in South Africa, from theory to Practice. A thesis submitted for the degree of Doctor of Education, Harvard University, New York.

Ozigi, A. O. (1982). A handbook on school administration and management. Ibadan.

Sithole, S. (1998). The participation of students in democratic school governance. In M. Magadla (2007), The Role of the Learner in the School Governing Body: Perceptions and Experiences of Principals, Educators, Parents and Learners (Unpublished Med thesis). University of Kwazulu- Natal.

Standa, E. M. (2008). Purpose and process of accreditation of universities in Kenya. In Stakeholders Workshop on Enhancing Quality in Higher Education in Kenya. Held at Kenya College of Communication and Technology from 13th to 15th August 2008.

UNESCO. (2008). Better schools: Resource materials for school heads in Africa. London: Commonwealth Secretariat Education Programme, Human Resource Development Group Marlborough House

Wilson, S. (2000). Schooling for democracy: issues on student participation. Youth Studies Australia, 19(2), 25-31.

Yuen, T. W. W., \& Leung, Y. W. (2010). Engaging students in school governance: A case study of the challenges and way forward. Journal of the Commonwealth Council for Educational Administration and Management, $38(3), 57-79$.

\section{Copyrights}

Copyright for this article is retained by the author(s), with first publication rights granted to the journal.

This is an open-access article distributed under the terms and conditions of the Creative Commons Attribution license (http://creativecommons.org/licenses/by/4.0/). 